\title{
KAJIAN DAS BATANG BAYANG DAN TAMBAHAN DEBIT ALIRAN DARI BATANG SIKABAU UNTUK MEMENUHI KEBUTUHAN AIR DAERAH IRIGASI BATANG BAYANG
}

\author{
Darwizal Daoed ${ }^{1}$, Bujang Rusman², Bambang Istijono ${ }^{3}$, \\ Abdul Hakam ${ }^{4}$ dan Rudy Ferial ${ }^{5}$
}

\begin{abstract}
ABSTRAK
Bukit Barisan dengan hutan yang masih asli dan curah hujan yang cukup tinggi menjadikan provinsi Sumatera Barat umumnya dan Pasaman Barat khususnya mempunyai banyak daerah aliran sungai (DAS) yang dapat mengalirkan air melalui sungai/batang hingga bermuara di lautan Indonesia. Akan tetapi perubahan fungsi hutan dan iklim menyebabkan debit air yang diprediksi mampu mengairi areal pertanian seluas 10.000 ha di daerah irigasi Batang Bayang pada kenyataannya tidak dapat terpenuhi. Pada makalah ini akan dikaji kemampuan DAS Batang Bayang dan Batang Sikabau masing-masingnya. Kemudian kedua DAS ini diintegrasikan, sehingga debit andalan yang terjadiakan lebih besar. Untuk menggabungkan debit air dari dua DAS dilakukan dengan metode suplesi, yakni membuat saluran yang menghubungkan Batang Sikabau ke saluran induk di DI Batang Bayang. Hasil kajian menunjukan bahwa areal irigasi Batang Bayang dapat diairi lebih dari 5.140,20ha untuk tanaman padi dan lebih dari 41.956,36 hauntuk palawija. Diharapkan dampak secara tidak langsung dari saluran suplesi akan mengurangi debit banjir di Batang Sikabau bagian hilir.
\end{abstract}

Kata kunci : Integrasi, Batang, Bayang, Sikabau, Suplesi.

\section{LATAR BELAKANG}

Sumatera Barat terletak pada pantai Barat Sumatera yang dibatasi bukit barisan pada sebelah Timur, sebelah Utara berbatasan dengan provinsi Sumutera Utara dan Selatan dengan Provinsi Jambi dan Bengkulu. Secara topografi Sumbar memiliki lahan berbukit dan bergelombang serta landai di daerah pinggiran pantai. Dengan adanya bukit ini menjadikan daerah ini mempunyai banyak daerah aliran sungai (DAS) yang dapat dikategorikan kecil, yakni luas DAS kurang dari $30 \mathrm{~km} 2$ (Report BWS - 2008).

Daerah perbukitan dan ditunjang dengan luasnya daerah hutan atau hutan lindung memberikan sumbangan positif terhadap banyaknya kantong-kantong air. Kantong-kantong air ini akan memberikan kelestarian air (persediaan air berkelanjutan), apabila dapat dipertahankan hutannya dari kegiatan manusia berupa penebangan pohon dan ladang berpindah. Lebih lanjut kantong air dapat didefinisikan dengan daerah tampungan air hujan di daratan, kemudian airnya mengalir ke sungai atau batang atau aliran bawah tanah dan berakhir ke danau atau ke laut secara alami, maka cakupan daerah ini disebut daerah aliran sungai(UU No. 7 Tahun 2004).

\footnotetext{
${ }^{I}$ Staf Pengajar Jurusan Teknik Sipil Fakultas Teknik Universitas Andalas, darwizaldaoed@ft.unand.ac.id

${ }^{2}$ StafPengajarJurusanTanah/ Prodi Agroekoteknologi Fakultas Pertanian UniversitasAndalas

${ }^{3}$ Staf Pengajar Jurusan Teknik Sipil Fakultas Teknik Universitas Andalas, bistijono1452@yahoo.co.id

${ }^{4}$ Staf Pengajar Jurusan Teknik Sipil Fakultas Teknik Universitas Andalas, ahakam2008@yahoo.com

${ }^{5}$ Staf Pengajar Jurusan Teknik Sipil Fakultas Teknik Universitas Andalas, rudyferial@ft.unand.ac.id
} 
Sungai atau batang dari DAS khusus di Sumbar terlihat lebih dominan mengalirkan air ke arah Barat dan bermuara di lautan Indonesia dibandingkan dengan yang mengalir ke pantai Timur Sumatera. Sungai -sungai atau batang yang mengalir ke Barat relatif lebih pendek dan meliwati daerah curam (steep) ke landai (mild) dibandingkan dengan yang mengalir ke arah Timur, dimana sungai yang ke arah Timur melalui provinsi Riau atau Jambi yang relatif landai (mild). Pada gambar-1 terlihat peta topografi Sumatera Barat dan gambar -2 sungai-sungai yang mengarah ke Barat.

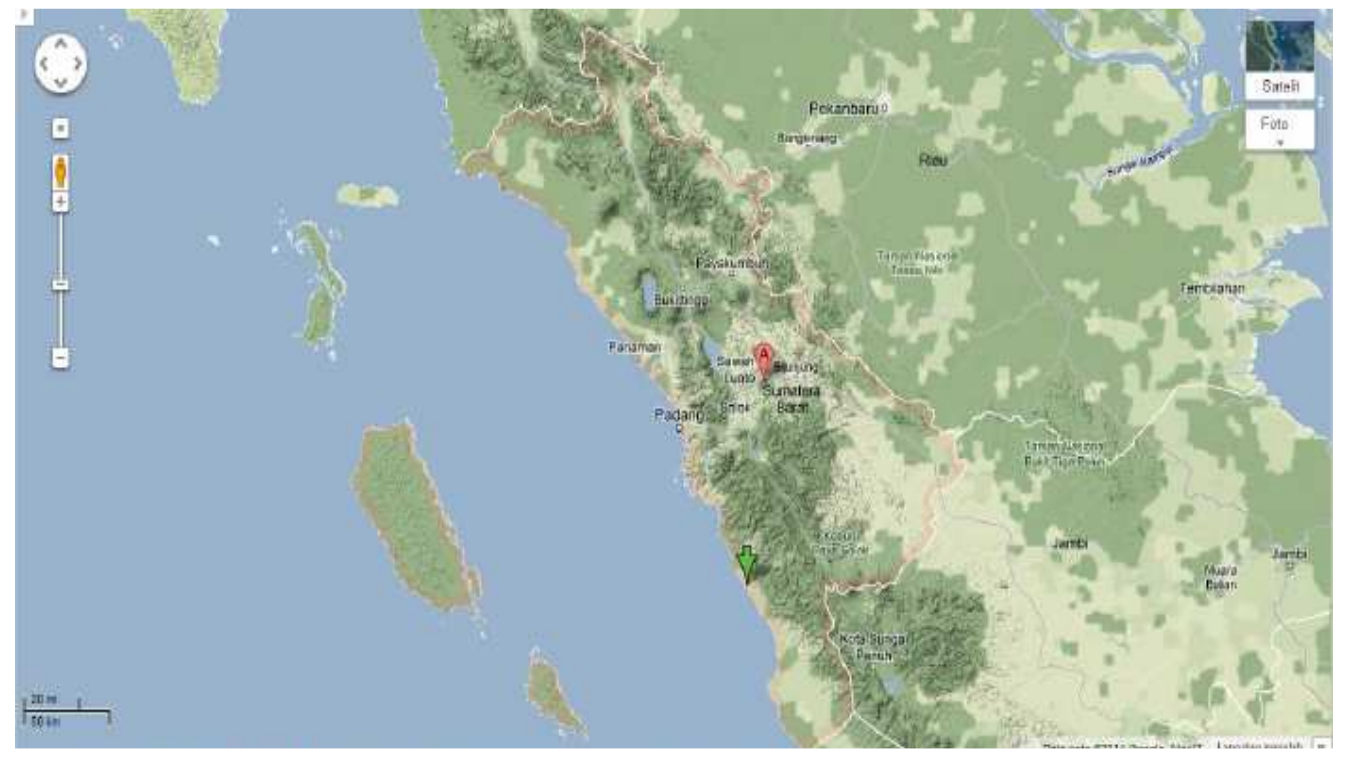

Gambar 1 Topografi Sumatera Barat

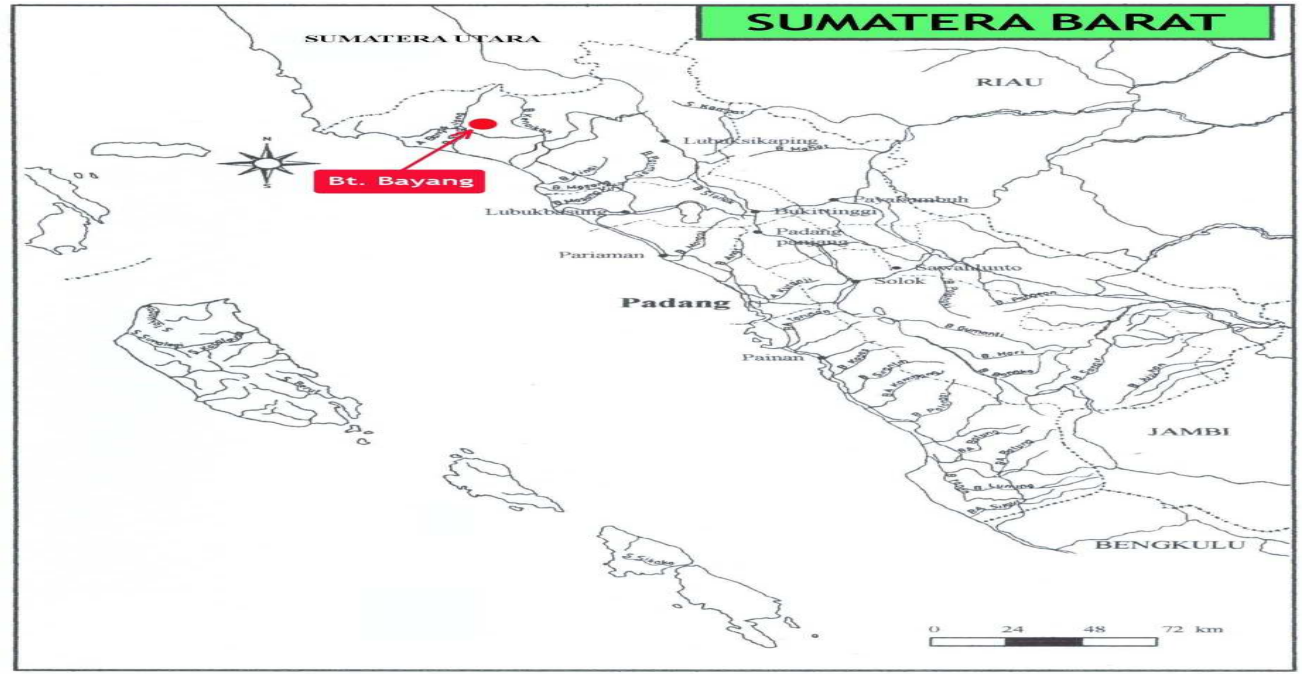

Gambar 2 Sungai atau Batang yang mengarah ke Barat dan Lautan Indonesia

Pada daerah perbukitan Sumatera yang merupakan cakupan DAS mengalami curah hujan cukup tinggi setiap tahunnya, sehingga banyak menyumbang air. Tetapi akibat perilaku manusia yang melakukan kegiatan penebangan pohon, pembukaan lahan pertanian dan perkebunan menjadikan curah hujan yang jatuh di DAS lebih cepat mengalir (surface run off), lebih besar dan sebaliknya infiltrasi atau resapan air lebih kecil. Akibatnya fungsi DAS menjadi berubah dan konsekuensinya bencana banjir sering terjadi di lokasi muara sungai. 
Disamping itu perubahan iklim (climate changes) akhir-akhir ini, yang sangat mempengaruhi hasil perhitungan dengan teori pendekatan peramalan (forcasting) terhadap besarnya curah hujan dan waktu terjadinya hujan yang sangat berbeda. Sebagai contoh menurut peramalan bulan Maret sampai dengan Juni musim kemarau, kenyataanya pada bulan tersebut terjadi hujan, sedangkan bulan September hingga November diperkirakan hujan tetapi tidak turun hujan.

Akibat aktifitas masyarakat yang tak terkontrol pada DAS dan perubahan iklim menyebabkan debit air yang mampu disimpan dan yang dialirkan cendrung menurun. Sehingga banyak ditemui lokasi yang pada awalnya potensial untuk lahan pertanian, tetapi setelah direalisasikan air yang mengalir tidak mencukupi. Hal ini sering memberikan dilema bagi sarjana teknik sipil maupun praktisi lainnya. Secara teoritis dapat dipertanggungjawabkan, bahwa air yang diprediksi dapat memenuhi kebutuhan. Kenyataannya beberapa lahan tidak mampu diairi. Walaupun telah dilakukan dengan mengoptimalkan pola tanam, yakni dengan memvariasikan jenis tanaman yang akan ditanam serta luasan areal pertanian.

Untuk mengatasi masalah ini perlu dilakukan terobosan untuk memenuhi debit air, yakni dengan mengintegrasikan (integrate) DAS yang berdekatan, sehingga debit air yang dibutuhkan dapat terpenuhi. Penggabungan DAS ini merupakan salah satu metode untuk mengefektifkan fungsi saluran irigasi yang telah ada.

Pada makalah ini dilakukan studi kasus pada Batang Sikabau yang digabungkan dengan Batang Bayang Kecamatan Lembah Malintang Kabupaten Pasaman Barat Provinsi Sumatera Barat.

\section{TINJAUAN PUSTAKA}

\subsection{Potensi dan Kerentanan DAS}

Daerah aliran sungai adalah suatu kesatuan wilayah tata air yang terbentuk secara alamiah, dimana air hujan yang turun di lahan tersebut, mengalir melalui sungai dan anak sungai yang bersangkutan(Kodoatie 2002). Sebagian air hujan yang turun diatas lahanmeresap dan mengalir secara alamiah ke hilirsecara gravitasi, yang dikenal dengan aliran bawah tanah. Sedangkan air yang mengalir merupakan bagian dari yang tertampung disebut aliran permukaan (surface run off), (K. Subramanya 2008).

Banjir yang membawa sedimen dapat terjadi, apabila nilai kerentanan lahan terhadap erosi antara 1,7- 4,3 (Paimin et al.,2010).Nilai kerentanan/sensitivitas lahan atau daerah tangkapan air (catchment area) tersebut sangat tergantung kepada tipologi lahan dan tipologi sosial ekonomi. Dimana tipologi lahan berupa karakter alamiah lahan yang relatif statis, yaitu:bentuk lahan, geologi, lereng, dan iklim yang tersusun dalam satuan/unit sistem lahan dan karakter dinamis yakni, kegiatan yang dilakukan manusia pada lahan tersebut. Sedangkan tipologi sosial ekonomi berupa pertumbuhan ekonomi penduduk dan struktur ekonomi daerah (Paimin, et al., 2013).

\subsection{Integrasi DAS}

Begitu banyaknya DAS yang ada terlihat banyak yang belum termanfaatkan secara maksimal. Kendalanya adalah antara lain sungai yang ada mengalirkan air dengan debit relatif kecil atau daerah pertanian (sawah) belum dibangun. Disisi lain memang sudah ada DAS yang telah dimanfaatkan airnya, tetapi debit air yang tersedia tidak mampu mengairi semua daerah irigasi, sebagai contoh pada DAS di Sumatera Barat yang bermuara ke lautan Indonesia atau biasa disingkat DAS Akuaman yang mempunyai banyak daerah irigasi (BWS-2008). 
Penggabungan (interagation) beberapa daerah aliran sungai (DAS) pada DAS Akuaman dapat merubah statusdaerah irigasi (DI) yangkekurangan air menjadi kecukupan air. Setelah dilakukan simulasi, maka diperolehhampir seluruh daerah irigasi yang ada diwilayah sungai Akuaman mampu diairi dengan keandalan lebih dari 80\%.(Daoed, dkk 2014).

Adapun konsep integrasi adalah menambahkan debit air ke saluran induk yang telah ada dengan menggunakan saluran penghubung atau saluran suplesi. Secara skematik dapat digambarkan sebagai berikut:

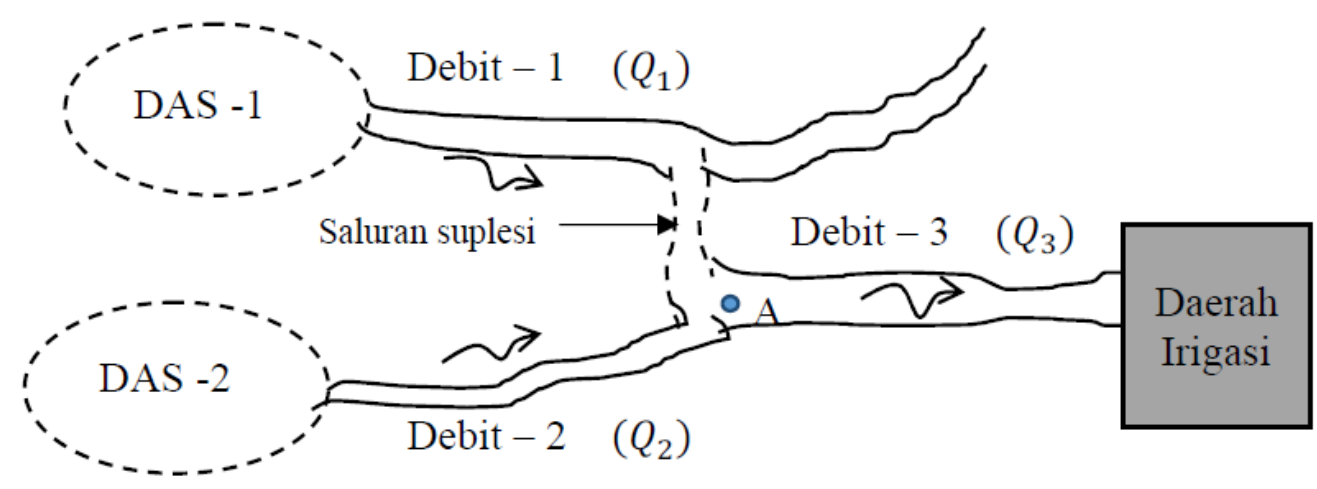

Gambar 3 Skematik Penambahan Debit Aliran dengan Saluran Suplesi

Penambahan debit aliran secara hidrolik diformulasikan sebagai berikut:

$$
\mathrm{Q}_{1}+\mathrm{Q}_{2}=\mathrm{Q}_{3}
$$

$\mathrm{Q}_{1}=$ debit aliran di saluran/ sungai -1 dari DAS-1

$\mathrm{Q}_{2}=$ debit aliran di saluran/ sungai -2 dari DAS-2

$\mathrm{Q}_{3}=$ debit aliran di saluran/ sungai -3 untuk mengairi DI.

Debit air yang memasuki titik kumpul (A) samadengan debit air yang meninggalkan titik kumpul (A) dari sistem atau jumlah total debit aliran sama dengan nol (Daoed 2010).

\section{METODOLOGI}

Penelitian dilakukan di daerah irigasi Batang Bayang Kecamatan Lembah Malintang Kabupaten Pasaman Barat. Dimana lahan pertanian sebagian tidak mampu diairi, maka dilakukan upaya menggabungkan dua DAS yang berdekatan.

Data yang digunakan data sekunder seperti curah hujan dan iklim dan mengkaji ulang hasil studi dan ivestigasi dari laporan yang ada di BWS V tahun 2005, berupa potensi dan debit andalan terhadap masing-masing DAS. Sedangkan untuk kebutuhan air tanaman dilakukan simulasi terhadap pola penanaman padi-padi, padi-padi-padi dan padi-padi-padi/palawija. 


\section{HASIL KAJIAN DAN PEMBAHASAN}

\subsection{Kondisi Daerah Irigasi Batang Bayang}

Daerah Pasaman Barat mempunyai banyak sekali sungai antara lain Batang Bayang, Batang Sikabau kecil, Batang Sikabau dan lain lain. Juga memiliki pos penakar curah hujan, yakni stasiun Ujung Gadiang di Ujung Gadiang dan Stasiun Silaping di Pasaman Barat yang memasok data kilimatologi.

Daerah irigasi Batang Bayang dibangun Tahun 1977 direncanakan mampu mengairi lahan pertanian sekitar 10.000 ha, dimana sumber air diperoleh dari Batang Bayang. Berdasarkan informasi dari masyarakat dan pengelola Satuan wilayah Sungai (SWS) Anai Sualang, debit air yang ada tidak dapat mengairi lahan seluas tersebut. Dimana hanya mampu mengairi lahan seluas 2.500 ha, sehingga banyak areal sawah yang menjadi lahan tidur dan sebagian berubah menjadi kebun sawit dan coklat.

\subsection{Kajian Kerentanan Daerah Aliran Sungai}

Hasil survey diperoleh bahwa kepadatan penduduk termasuk ke dalam kelompok sedang, yakni lebih dari $500 \mathrm{org} / \mathrm{km} 2$ dan struktur ekonomi penduduk dominan pertanian dan jasa, maka dapat simpulkan bahwa nilai kerentanan terhadap tipologi lahan adalah 5 dan nilai tipologi ekonomi adalah 2,0 dengan pendapatan 1,1 - 1,25 dari standar kemiskinan (SK). Dari kedua nilai di atas diperoleh klasifikasi tipologi atau kerentanan lahan terhadap erosi adalah antara 3,5 - 4,3 termasuk kategori tinggi. Walaupun kepadatan penduduk meningkat menjadi700 org/km2 nilai kerentanan lahan tetap kategori tinggi, karena nilai tipologi lahan 5 untuk kepadatan penduduk lebih dari 400 org $/ \mathrm{km}^{2}$.

\subsection{Potensi Air dan Integrasi DAS}

Berdasarkan hasil kajian dan laporan akhir dari BWS tahun 2005 diperoleh debit air banjir dari Batang Bayang untuk periode ulang $\mathrm{T}=50$ tahun sebesar $\mathrm{Q} 50=120 \mathrm{~m} 3 / \mathrm{s}$, sedangkan debit andalan rata-rata $1,0 \mathrm{~m} 3 / \mathrm{s}$ dan mampu mengairi sekitar 2500 ha. Dimana rencana sebelumnya luasan daerah yang harus diairi adalah 10.000 ha. Untuk itu diperlukan debit air yang lebih besar untuk mengairi lahan tersebut.

Tabel 1 Debit Banjir Rencana untuk DAS Batang Bayang dan Batang Sikabau

\begin{tabular}{|l|l|l|}
\hline $\begin{array}{l}\text { Peride Ulang (T) } \\
\text { tahun }\end{array}$ & $\begin{array}{l}\text { Debit Rencana Batang } \\
\text { Sikabau }\left(\mathrm{m}^{3} / \mathrm{s}\right)\end{array}$ & $\begin{array}{l}\text { Debit Rencana Batang } \\
\text { Bayang }\left(\mathrm{m}^{3} / \mathrm{s}\right)\end{array}$ \\
\hline 100 & 565 & 131 \\
\hline 50 & 516 & 120 \\
\hline 25 & 466 & 108 \\
\hline 20 & 449 & 105 \\
\hline 10 & 398 & 93 \\
\hline 5 & 345 & 81 \\
\hline 2 & 265 & 62 \\
\hline
\end{tabular}

Sumber: Report Executive, BWS,2005 
Integrasi Batang Bayang dan Batang Sikabau merupakan salah satu solusi untuk menyelesaikan kasus. Alternatif ini diambil karena sungai ini berdekatan DAS nya dan DAS Batang Sikabau mempunyai debit air yang cukup besar. Hasil analisa hidrologi untuk kedua DAS ini diperoleh debit banjir rencana masing-masingnya, seperti pada Tabel 1.

\subsection{Debit Andalan}

Batang Sikabau dan Batang Bayang secara topografiyang hampir sama dan mempunyai curah hujan yang dianggap sama (data curah hujan terbatas). Hasil pengamatan curah hujan harian dari pos Ujung Gading digunakan untuk menghitung debit aliran dan evapotranspirasi dilakukan dari data pengamatan stasiun Silaping.

Pada gambar-4 terlihat debit andalan dari DAS Batang Sikabau hampir tiga kali lipat dari DAS Batang Bayang. Tentu gambaran ini tambah meyakinkan, bahwa dengan penambahan (suppletion) debit air mampu mengairi seluruh areal pertanian. Meskipun debit air mengalami pengurangan akibat resapan dan evaporasi sepanjang pengaliran baik pada saluran induk maupun saluran suplesi.

\subsection{Kebutuhan Air Irigasi}

Analisa kebutuhan air dilakukan untuk memenuhi debit air yang dibutuhkan pada DI. Batang Bayang, bagian ini dilakukan simulasi terhadap kemungkinan pola tanam. Dimana perhitungan kebutuhan air dilakukan dengan mevariasikan pola tanama Padi-Padi, Padi-padi-padi dan Padipadi-padi/palawija dengan dua alternatif jadwal mulai tanam, yakni Oktober-1 dan Oktober-2. Hasil simulasi dan perhitungan kebutuhannya seperti pada Tabel 2.

\subsection{Volume Andalan}

Volume andalan adalah volume air paling sedikit yang mampu diadakan. Volume andalan untuk Batang Bayang dan Batang Sikabau dalam melayani kebutuhan air daerah irigasi Batang Bayang, dihitung berdasarkan pola tanam yang diusulkan di atas. Volume air andalan setelah suplesi batang Sikabau ke batang Bayang, seperti pada Tabe 3 .

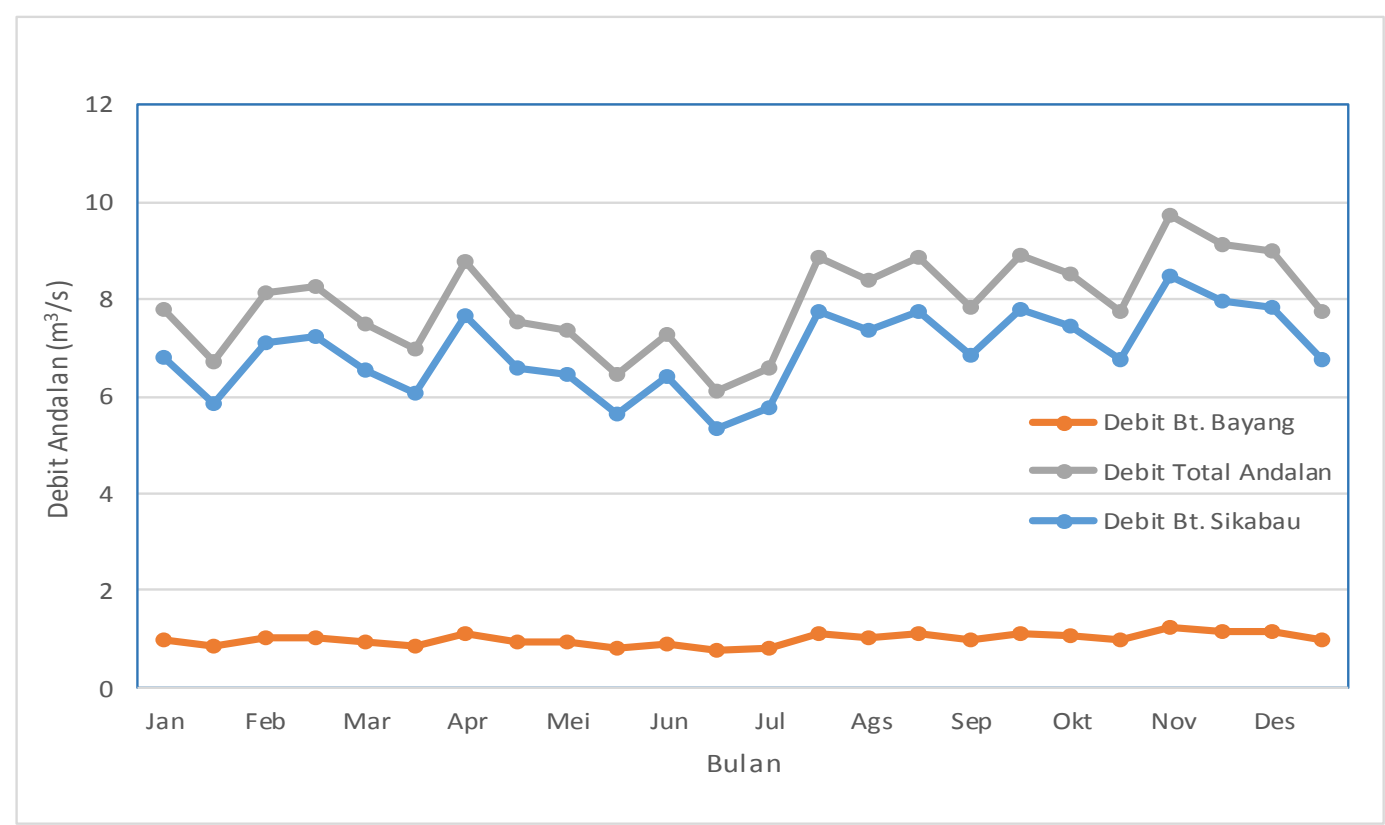

Gambar 4 Debit Andalan Batang Bayang dan Batang Sikabau dalam Setahun Sumber: Report Executive, BWS,2005 
Tabel 2 Kebutuhan Air Masing-masing Pola Tanam

\begin{tabular}{|c|c|c|c|c|c|}
\hline \multirow[t]{2}{*}{ No. } & \multirow[t]{2}{*}{ Pola Tanam } & \multirow[t]{2}{*}{ Awal Tanam } & \multirow{2}{*}{$\begin{array}{l}\text { Musim } \\
\text { Tanam }\end{array}$} & \multicolumn{2}{|c|}{ Kebutuhan Air Irigasi $\left(m^{3} / h a\right)$} \\
\hline & & & & Padi & Palawija \\
\hline \multirow{6}{*}{1} & \multirow{6}{*}{ Padi-padi } & \multirow{3}{*}{ Oktober-1 } & $\mathrm{I}$ & 974 & - \\
\hline & & & II & 980 & - \\
\hline & & & III & - & - \\
\hline & & \multirow{3}{*}{ Oktober-2 } & I & 973 & - \\
\hline & & & II & 1006 & - \\
\hline & & & III & - & - \\
\hline \multirow{6}{*}{2} & \multirow{6}{*}{ Padi-padi-padi } & \multirow{3}{*}{ Oktober-1 } & I & 961 & - \\
\hline & & & II & 1019 & - \\
\hline & & & III & 976 & - \\
\hline & & \multirow{3}{*}{ Oktober-2 } & $\mathrm{I}$ & 956 & - \\
\hline & & & II & 1016 & - \\
\hline & & & III & 976 & - \\
\hline \multirow{6}{*}{3} & \multirow{6}{*}{ Padi-padi-palawija } & \multirow{3}{*}{ Oktober-1 } & I & 974 & - \\
\hline & & & II & 1025 & - \\
\hline & & & III & - & 37 \\
\hline & & \multirow{3}{*}{ Oktober-2 } & I & 960 & - \\
\hline & & & II & 1002 & - \\
\hline & & & III & - & 132 \\
\hline
\end{tabular}

Tabel 3 VolumeAndalan Sungai Batang Bayang dan Sikabau

\begin{tabular}{|l|l|l|}
\hline \multirow{2}{*}{ Musim Tanam } & Volume Andalan $\left(\mathrm{m}^{3}\right)$ \\
\cline { 2 - 3 } & Oktober-I & Oktober-II \\
\hline I & 5732640 & 5698080 \\
\hline II & 5268672 & 5196096 \\
\hline III & 5431104 & 5538240 \\
\hline
\end{tabular}

\subsection{Prakiraan Luasan Lahan Irigasi yang Mampu Diairi}

Dengan memperhatikan kebutuhan air dan besarnya volume andalan yang dapat diadakan dari penggabungan dua sungai sekaligus DAS masing-masingnya, maka dapat diestimasi luas lahan yang dapat diairi. Tentunya dengan mempertimbangkan pola tanam yang diusulkan di atas. Hasil prakiraan dapat dilihat pada Tabel 4.

\section{PEMBAHASAN}

Bila diamati daerah aliran sungai pada daerah Pasaman Barat, masih memiliki kerentanan yang tinggi, sehingga perlu pengamatan yang rutin agar dapat diatasi sedimentasi yang akan terjadi. Terutama pada daerah penggabungan DAS, dimana kemungkinan terjadi penumpukan material hanyutan pada pertemuan batang Bayang dengan saluran suplesi.

Dari simulasi terhadap pola penanaman padi dan palawija, maka luasan sawah yang dapat diairi adalah 5140,20ha dan palawija 146.786,59 ha untuk awal tanam oktober-1, sedangkan untuk oktober-2 luasan sawah 5185,7 ha dan palawija 41.956,36 ha. Disini terlihat bahwa untuk 
penanaman palawija saja jauh lebih besar dari luasan daerah irigasi yang ada, sedangkan untuk sawah saja sekitar 5.100 ha lebih.

Tabel 4 Prakiraan Luasan Daerah Irigasi yang Mampu Diairi Per Pola Tanam

\begin{tabular}{|c|c|c|c|c|c|c|c|c|c|c|}
\hline \multirow[t]{2}{*}{ No. } & \multirow[t]{2}{*}{ Pola Tanam } & \multirow[t]{2}{*}{$\begin{array}{l}\text { Awal } \\
\text { Tanam }\end{array}$} & \multirow[t]{2}{*}{$\begin{array}{l}\text { Musim } \\
\text { Tanam }\end{array}$} & \multicolumn{2}{|c|}{$\begin{array}{c}\text { Kebutuhan Air } \\
\text { Irigasi } \\
\left(m^{3} / h a\right)\end{array}$} & \multirow[t]{2}{*}{$\begin{array}{c}\text { Volume air } \\
\text { yang dapat } \\
\text { diadakan } \\
\left(\mathrm{m}^{3}\right)\end{array}$} & \multicolumn{2}{|c|}{$\begin{array}{c}\text { Prakiraan Luasan yang } \\
\text { dapat diairi }(h a)\end{array}$} & \multicolumn{2}{|c|}{$\begin{array}{c}\text { Luas Total } \\
\text { Minimum }(h a)\end{array}$} \\
\hline & & & & Padi & Palawija & & Padi & Palawija & Padi & Palawija \\
\hline & & & I & 974 & - & 5732640 & 5885,67 & - & 5376,2 & - \\
\hline & & Okt-01 & II & 980 & - & 5268672 & 5376,20 & - & - & - \\
\hline \multirow[t]{6}{*}{1} & Padi-padi & & III & - & - & 5431104 & - & - & - & - \\
\hline & & & I & 973 & - & 5698080 & 5856,20 & - & 5165,1 & - \\
\hline & & Okt-02 & II & 1006 & - & 5196096 & 5165,11 & - & - & - \\
\hline & & & III & - & - & 5538240 & - & - & - & - \\
\hline & & & I & 961 & - & 5732640 & 5965,29 & - & 5170,4 & - \\
\hline & & Okt-01 & II & 1019 & - & 5268672 & 5170,43 & - & - & - \\
\hline \multirow[t]{6}{*}{2} & Padi-padi-padi & & III & 976 & - & 5431104 & 5564,66 & - & - & - \\
\hline & & & I & 956 & - & 5698080 & 5960,33 & - & 5114,3 & - \\
\hline & & Okt-02 & II & 1016 & - & 5196096 & 5114,27 & - & - & - \\
\hline & & & III & 976 & - & 5538240 & 5674,43 & - & - & - \\
\hline & & & $\mathrm{I}$ & 974 & - & 5732640 & 5885,67 & - & 5140,2 & - \\
\hline & & Okt-01 & II & 1025 & - & 5268672 & 5140,17 & - & - & - \\
\hline \multirow[t]{4}{*}{3} & Padi-padi-palawija & & III & - & 37 & 5431104 & - & 146786.59 & - & 146786.59 \\
\hline & & & I & 960 & - & 5698080 & 5935,50 & - & 5185,7 & - \\
\hline & & Okt- 02 & II & 1002 & - & 5196096 & 5185,72 & - & - & - \\
\hline & & & III & - & 132 & 5538240 & - & 41956,36 & - & 41956,36 \\
\hline
\end{tabular}

Jadi dengan menggabungkan daerah aliran sungai dapat meningkatkan kinerja layanan daerah irigasi yang mampu diairi. Walaupun sawah yang mampu diairi setengah dari luasannya. Sehingga untuk mengoptimalkan pemanfaatan air yang ada, maka perlu dilakukan simulasi terhadap luasan daerah pertanian dansekaligus dapat memaksimalkan produksihasil pertanian. Tentu secara langsung dapat meningkatkan pendapatanmasyarakat setempat.

Secara tidak langsung dengan penggabungan DAS dapat mengurangi debit banjir yang meliwati Batang Sikabau hilir, karena debit air sebagian sudah dialihkan ke saluran suplesi dan masuk ke saluran induk irigasi batang Bayang. Dengan demikian saluran suplesi dapatberfungsi sebagai saluran pengendali banjir (flood control).

\section{KESIMPULAN}

1. DAS batang Bayang masih diklasifikasikan tipologi atau kerentanan lahan terhadap erosi adalah antara 3,5-4,3 termasuk kategori tinggi.

2. Dengan melakukan penggabungan DAS dapat memperbaiki kinerja daerah irigasi Batang Bayang dari hanya mampu diairi sekitar 2.500 ha dapat ditingkatkan menjadi minimum sekitar 5140,20ha untuk tanaman padi dan 41.956,36 hauntuk tanaman palawija.

3. Debit air yang dibutuhkan dapat terpenuhi dan jauh lebih besar dari pada dipakai DAS yang terpisah.

4. Saluran suplesi disamping sebagai saluran pembawa air, juga dapat berfungsi sebagai saluran pengendali banjir.

\section{SARAN}


Perlu dikaji lebih lanjut pengaruh back water lokasi pertemuan saluran suplesi dan saluran induk Batang Bayang, karena akan menimbulkan banjir setempat di muara tersebut.

\section{UCAPAN TERIMAKASIH}

Ucapan terima kasih penulis tujukan kepada Kepala dan Staf BWS - V - Parak Kopi - Padang yang telah mengizinkan untuk memakai Executive Report SID Batang Bayang sebagai data sekunder, Dekan Fakultas Teknik Universitas Andalas, serta Tim Pembimbing Program Doktor yang telah membantu dalam penyempurnaan makalah ini.

\section{DAFTAR KEPUSTAKAAN}

Balai Wilayah Sungai - V, (2005) Executive Report Studi dan Investigasi DI Batang Bayang Pasaman Barat, Padang.

Balai Wilayah Sungai, (2008)Executive Report Rencana Pola Pengelolaan Sumber Daya Air Wilayah Sungai Akuaman, Sumatera Barat, Padang.

Daoed, D., Bujang R., Bambang I., Abdul H., (2014) Integrasi Daerah Aliran Sungai Kecil untuk Memenuhi Kebutuhan Air Menggunakan Saluran Suplesi, Prosiding PIT 31, pp. 177-184., Padang.ISBN: 978-97998805-7-4.

Daoed, Darwizal, (2010) Hidrolika dan Terapan untuk Saluran Terbuka,pp 9-10, CV Ferila, Padang,ISBN : 978-602-9081-08-4.

Kodoatie, R.; Sugiyanto, (2002) Banjir Beberapa Penyebab dan Metode Pengendaliannya dalam Perspektif Lingkungan, pp 74, 216-217, Pustaka Pelajar, Yogyakarta, ISBN: 979-9483-46-8.

Paimin, Irfan BP., Purwanto, Dewi RI., (2013) Sistem Perencanaan Pengelolaan Daerah Aliran Sungai, Pusat Penelitian Pengembangan Konservasi dan Rehabilitasi, pp19-21, Bogor Indonesia, ISBN: 978-60299218-2-3.

Paimin, Sukresno, Purwanto, (2010) Sidik Cepat Degradasi Sub Daerah Aliran Sungai (Sub. DAS), Puslitbang Hutan dan Konservasi Alam, Badan Litbang Kehutanan, Dept. Kehutanan Bogor,Cetakan Kedua.

Subramanya, K., (2008) Engineering Hydrology, 3rd Edition Tata Mc.Graw-Hill, New Delhi, ISBN: 978-007-064855-5.

Subramanya, K., (2009) Flow in Open Channels, Mc.Graw-Hili Int. Edition, Singapore, ISBN: 979-007$127239-1$.

Undang-Undang Republik Indonesia No. 7 Tahun 2004, tentang Sumberdaya Air, Tambahan Lembaran Negara Republik Indonesia Tahun 2004, No. 32 Fokus Media Bandung. 